\title{
Geoquatia
}

Malavsian Ioumal of Societvand Space

\section{Pembentukan model faktor bahan dan peralatan sebagai penyebab kemalangan dalam industri pembinaan Mass Rapid Transit}

\author{
Mohammad Lui Juhari ${ }^{1}$, Kadir Arifin ${ }^{1}$ \\ ${ }^{1}$ Program Sains Pembangunan, Pusat Kajian Sosial, Pembangunan dan Persekitaran, \\ Universiti Kebangsaan Malaysia
}

Correspondence: Kadir Arifin (email: kadir@ukm.edu.my)

Received: 28 June 2019; Accepted: 29 May 2020; Published: 30 May 2020

\begin{abstract}
Abstrak
Kadar kemalangan pekerjaan di industri pembinaan adalah di antara yang tertinggi berbanding sektor perindustrian yang lain. Faktor bahan dan peralatan merupakan antara penyumbang kepada kemalangan pekerjaan di tapak pembinaan berbanding dengan faktorfaktor lain. Kajian ini dijalankan bagi mencadangkan penilaian model faktor bahan dan peralatan dalam menyumbang kepada kemalangan pekerjaan dalam industri pembinaan Mass Rapid Transit di Malaysia (MRT) di Malaysia dengan menggunakan analisis faktor pengesahan (CFA). Kajian kuantitatif ini dijalankan dengan mengedarkan borang soal selidik secara rawak untuk mendapatkan data bagi projek pembinaan MRT di sekitar Lembah Kelang. Sebanyak 180 maklumbalas responden telah diterima merangkumi kumpulan pengurusan/profesional dan kumpulan pekerja pembinaan. Kemudian, analisis CFA dijalankan menggunakan perisian IBM SPSS-AMOS bagi mengesahkan model cadangan dengan memeriksa perhubungan di antara pemboleh ubah yang diperhatikan dan pemboleh ubah pendam. Pemboleh ubah pendam adalah faktor bahan dan peralatan; aspek kesesuaian bahan dan peralatan "sesuai"; keadaan bahan dan peralatan "keadaan"; rekabentuk perlindungan keselamatan "rekabentuk"; dan pengetahuan mengenai bahan dan peralatan yang digunakan "pengetahuan". Manakala pemboleh ubah yang diperhatikan merupakan 19 item bagi keempat-empat aspek di bawah faktor bahan dan peralatan. Keputusan CFA mengesahkan bahawa faktor bahan dan peralatan dalam menyumbang kepada kemalangan pekerjaan dalam industri pembinaan MRT adalah terdiri daripada keempat-empat aspek yang dikaji iaitu "pengetahuan", "rekabentuk", "keadaan", and "sesuai". Hasil dapatan kajian ini perlu diberi perhatian oleh semua pemegang taruh dengan mengambil langkah-langkah penambahbaikan yang bersesuaian dalam usaha untuk mencegah kemalangan pekerjaan di industri pembinaan MRT pada masa akan datang.
\end{abstract}

Katakunci: analisis faktor pengesahan, faktor bahan dan peralatan, industri pembinaan, kemalangan pekerjaan, keselamatan dan kesihatan pekerjaan, mass rapid transit 


\title{
Development of materials and equipment factor model in contributing to accidents in the Mass Rapid Transit construction industry
}

\begin{abstract}
Occupational accident rates in the construction industry are among the highest compared to other industrial sectors. Materials and equipment factor is one of the contributing to occupational accidents in the construction industry. This study was conducted with objective to propose an assessment of the materials and equipment factor model in contributing to occupational accidents in the Mass Rapid Transit di Malaysia (MRT) construction industry in Malaysia by using confirmatory factor analysis (CFA). This quantitative research was conducted by distributing a survey questionnaire randomly to obtain data from the MRT construction project around the Klang Valley. A total of 180 respondent responses were received from management/ professional and construction site workers group. Then, CFA analysis was performed by using IBM SPSS-AMOS to validate the proposed model by examining the relationships between observed variable and latent variable. Latent variable are materials and equipment factor; suitability of the materials/equipment; conditions of the material/equipment; safety protection design; and knowledge of the materials/equipment used. Whereas the observed variables are 19 items for all four aspects under materials and equipment factor. The CFA result validates that the materials and equipment factor in contributing to occupational accidents in the MRT construction industry is consist of all four aspects studied i.e. "knowledge", "design", "condition", and "suitable". This result of research should be focused by all MRT construction stakeholders where suitable improvement measures can be taken in order to prevent occupational accidents from occurring in the future.
\end{abstract}

Keywords: confirmatory factor analysis, materials and equipment factors, construction industry, occupational accidents, occupational safety and health, mass rapid transit

\section{Pengenalan}

Industri pembinaan merupakan industri yang mempunyai risiko tinggi untuk berlakunya kemalangan pekerjaan kerana industri tersebut berubah-rubah mengikut perkembangan fasa projek (Jaafar et al., 2018; Khosravi et al., 2014; Lee et al., 2020). Perkembangan ekonomi dan pembangunan yang pesat merupakan faktor yang menjadikan industri pembinaan merupakan salah satu industri yang paling berbahaya di dunia (Fass et al., 2017; Misiurek \& Misiurek, 2017). Industri pembinaan juga sering dilabelkan sebagai industri yang paling kerap berlakunya kemalangan dan kemalangan maut di tempat kerja (Hyoung et al., 2009). Ini disokong pula oleh Yoon et al. (2013) yang menyatakan bahawa kemalangan disebabkan pekerjaan dalam industri pembinaan berlaku setiap hari di tapak pembinaan di seluruh dunia.

Kemalangan pekerjaan sering dikaitkan dengan kesan negatif kepada industri pembinaan dan sekaligus melewatkan lagi tempoh penyiapan sesuatu projek yang telah ditetapkan. Reese dan Edison (2006) menyatakan bahawa kejadian kemalangan di tempat kerja boleh menyebabkan kehilangan pengeluaran syarikat, penyakit atau kecederaan, kerosakan peralatan atau harta, dan kejadian nyaris. Jabbari dan Ghorbani (2016) pula menambah bahawa kemalangan pekerjaan adalah melibatkan perbelanjaan yang besar kepada masyarakat, syarikat, dan juga individu yang terlibat. 
Di Malaysia, kadar kemalangan pekerjaan di industri pembinaan merupakan di antara yang tertinggi berbanding industri lain. Berdasarkan statistik yang dikeluarkan oleh Jabatan Keselamatan dan Kesihatan Pekerjaan (JKKP) Malaysia (2019), kadar kemalangan pekerjaan di industri pembinaan pada tahun 2015 mencatatkan angka sebanyak 2.98 per 1,000 pekerja. Angka kadar kemalangan pekerjaan tersebut terus menaik mendadak pada tahun 2017 dengan catatan sebanyak 3.40 per 1,000 pekerja (JKKP, 2019). Bagi kadar kemalangan maut pula, industri pembinaan merupakan yang tertingi di Malaysia berbanding sektor perindustrian lain bagi tahun 2015 hingga 2017 (JKKP, 2019). Lebih membimbangkan adalah kadar kemalangan maut di industri pembinaan menunjukkan tren peningkatan bagi setiap tahun di mana ia mencatatkan angka sebanyak 10.69 per 100,000 pekerja pada tahun $2015 ; 12.78$ per 100,000 pekerja pada tahun 2016; dan 14.57 per 100,000 pekerja pada tahun 2017 (JKKP, 2019).

Bagi industri pembinaan rel MRT di Malaysia pula, sebanyak 9 kes kemalangan maut; 10 hilang upaya kekal; dan 20 tidak hilang upaya kekal telah dilaporkan kepada DOSH Malaysia sepanjang lima tahun projek pembinaan MRT dijalankan bermula pada tahun 2012 hingga 2015 (JKKP, 2016a). Oleh yang demikian, usaha untuk mencegah berlakunya kemalangan pekerjaan di sektor ini perlu dipertingkatkan. Ini adalah kerana kemalangan pekerjaan, penyakit pekerjaan dan kemalangan nyaris merupakan indikator penting terhadap budaya keselamatan dan kesihatan pekerjaan (KKP) di sesebuah organisasi (Hughes \& Ferrett, 2005).

\section{Kajian literatur}

Pada masa kini, situasi kesesakan lalu lintas adalah salah satu masalah yang dihadapi bandarbandar di kawasan Lembah Klang terutamanya Kuala Lumpur disebabkan pertambahan populasi yang ketara (Jamilah, 2005). Terdapat banyak usaha telah dilaksanakan bagi menambahbaik sistem pengangkutan awam bagi memenuhi keperluan harian penduduk bandar (Dzuhailmi et al., 2015). Projek pembinaan MRT di sekitar kawasan Lembah Klang merupakan antara projek besar di bawah Program Transformasi Ekonomi (ETP). Projek ini melibatkan pembinaan jaringan pengangkutan awam yang berasaskan rel, yang akan berintegrasi dengan sistem-sistem transit aliran ringan atau Light Rail Transit (LRT), monorel, KTM Komuter, KLIA Ekspres dan KLIA Transit (MRT Corp., 2017). Situasi perkembangan projek pembinaan MRT yang rancak ini telah meningkatkan risiko untuk berlakunya kemalangan pekerjaan disebabkan oleh aktiviti-aktiviti pembinaan struktur yang tinggi dan pembinaan terowong bawah tanah yang tertumpu di kawasan pusat bandar Wilayah Persekutuan Kuala Lumpur, Selangor dan Wilayah Persekutuan Putrajaya.

\section{Faktor-faktor kemalangan pekerjaan}

Pengurusan KKP yang betul dan mantap di industri pembinaan rel adalah sangat penting untuk mencegah berlakunya kemalangan pekerjaan. Ini kerana pengurusan keselamatan pekerjaan yang baik akan memastikan keselamatan pekerja di tempat kerja (Arifin et al., 2013; Arifin et al., 2016). Ia ditambah pula dengan sifat projek pembinaan rel sebagai operasi berskala besar, berteknologi moden, struktur yang kompleks, standard teknikal dan kualiti yang tinggi, jangka masa yang lama, dan memerlukan jalinan kerjasama pelbagai pihak (Qing et al., 2014). Penyebab ataupun faktor kemalangan pekerjaan perlu difahami dengan jelas kerana ia merupakan langkah yang penting dalam proses pencegahan kemalangan pekerjaan (Kang \& Ryu, 2019; Khosravi et al., 2014). Faktor-faktor kemalangan boleh dikenalpasti dan diuruskan dengan baik bagi membendung kejadian kemalangan pekerjaan daripada berlaku. 
Choe dan Leite (2020) dan Khanzode et al. (2012) juga mempunyai pandangan yang sama dengan menyatakan bahawa faktor-faktor penyumbang kepada berlakunya sesuatu kemalangan di tempat kerja boleh dikenalpasti melalui teori-teori penyebab kemalangan pekerjaan. Justeru itu, faktor-faktor penyebab kepada kemalangan pekerjaan dalam industri pembinaan rel MRT perlu dikenal pasti dan dikaji bagi mengurus semua hazad dan risiko yang terdapat di industri tersebut dengan berkesan. Berdasarkan kepada teori dan model kemalangan penyelidik terdahulu, faktor penyumbang kemalangan pekerjaan yang sering dibincangkan boleh dibahagikan kepada lima iaitu faktor pekerja; tempat kerja; bahan dan peralatan; pengurusan; dan pengaruh persekitaran (Haslam et al., 2005; Hide et al., 2003; Stępień, 2014; Jaafar et al., 2015; Jaafar et al., 2018; Ismail et al., 2017).

Faktor bahan dan peralatan merupakan antara elemen yang penting dalam menyumbang kepada kemalangan pekerjaan di tapak pembinaan. Ini kerana menurut Misiurek dan Misiurek (2017), banyak mesin-mesin canggih telah dicipta bagi kegunaan kerja-kerja pembinaan dan ia telah merubah potensi berlakunya kemalangan pekerjaan disebabkan oleh pekerja yang mengendalikan mesin tersebut. Kajian yang dijalankan oleh JKKP (2014a) mengenai kemalangan di industri pembinaan rel mendapati bahawa kemalangan yang paling kerap berlaku adalah semasa pembinaan struktur yang tinggi (elevated viaduct) dengan peratusan tertinggi iaitu sebanyak 37 peratus. Kes-kes kemalangan tersebut adalah disumbangkan oleh faktor bahan dan peralatan yang digunakan semasa kerjakerja pembinaan. Contoh kemalangan pembinaan struktur yang tinggi yang menyumbang kepada statistik tersebut adalah seperti runtuhan jentera segmental box girder semasa proses pemasangan; runtuhan jentera launching girder; runtuhan acuan konkrit disebabkan bahan binaan yang tidak mengikut spesifikasi; runtuhan perancah disebabkan aspek keadaan dan rekabentuk dan lain-lain lagi (JKKP, 2014a). Oleh yang demikian, kajian ini dijalankan dengan tujuan untuk menganalisis dan menilai faktor bahan dan peralatan dalam menyumbang kepada kemalangan pekerjaan dalam industri pembinaan rel MRT.

\section{Faktor bahan dan peralatan}

Menurut Cao (2013) dan Filho et al. (2002), bahan dan peralatan kejuruteraan bagi industri pembinaan termasuklah bahan-bahan mentah, kemudahan-kemudahan; pepasanganpepasangan dan juga semi-produk yang digunakan bagi tujuan aktiviti pembinaan. Jentera dan peralatan pembinaan pula adalah asas yang penting semasa projek pembinaan. Bagi projek pembinaan rel berskala besar seperti projek MRT, bahan dan peralatan yang berteknologi tinggi dan kuantiti yang banyak adalah merupakan keperluan penting. Contohnya bagi proses pembinaan struktur yang tinggi (elevated viaduct), peralatan seperti mesin launching girder dan segmental box girders adalah diperlukan bagi menjalankan kerjakerja menanam cerucuk (piling); pemasangan span dan parapet wall; dan pembinaan tiang konkrit. Proses kerja bawah tanah pula memerlukan mesin yang canggih dan berteknologi tinggi seperti Tunnel Boring Machine (TBM) untuk menjalankan kerja-kerja penggalian bumi dan batu (MRT Corp., 2017).

Cao (2013) menyatakan bahawa kualiti dan prestasi bagi bahan-bahan kejuruteraan; jentera-jentera mekanikal pembinaan; dan peralatan pembinaan akan memberi kesan kepada aspek keselamatan dan kesihatan secara langsung. Haslam et al. (2005) pula melalui kajiannya telah mengenalpasti bahawa bahan dan peralatan termasuklah peralatan perlindungan peribadi (PPE) telah menyumbang kepada 56\% insiden kemalangan. Menurut Gürcanli dan Müngen (2013), bahan dan peralatan merupakan antara penyumbang kepada kemalangan pekerjaan di industri pembinaan. Contohnya kemalangan melibatkan pengendalian jentera berat; tersepit di bahagian mesin; dan kemalangan semasa proses pengangkutan bahan di tapak pembinaan (Gürcanli \& Müngen, 2013). Oleh itu, kawalan dan 
pemilihan terhadap bahan-bahan kejuruteraan; jentera-jentera mekanikal; dan peralatan pembinaan di dalam projek pembinaan MRT adalah penting bagi memberi impak yang positif terhadap prestasi keselamatan projek tersebut secara keseluruhannya.

Antara contoh kes kemalangan di industri pembinaan rel MRT yang melibatkan bahan dan peralatan adalah seperti kemalangan maut yang berlaku pada 30 Mei 2013 di Subang. Kejadian kemalangan terjadi apabila sebuah treler mengangkut boom kren ke tapak pembinaan MRT gagal mengikat peralatan berat dengan betul sehingga menyebabkan kemalangan apabila boom kren terjatuh dan terhempas ke sebuah kereta awam (JKKP, 2013). Punca kemalangan adalah dikaitkan dengan faktor peralatan iaitu elemen penilaian risiko dan pengetahuan mengenai peralatan dan jentera. Kemalangan tersebut telah mengakibat seorang mangsa maut manakala seorang lagi cedera parah. Selain daripada itu, pada 27 Februari 2015 seorang pekerja maut manakala seorang lagi pekerja cedera parah di tapak pembinaan projek MRT Semantan, Kuala Lumpur. Kemalangan maut tersebut berpunca daripada ikatan antara kerangka besi tetulang yang patah lalu struktur besi tersebut menghempap pekerja di tapak pembinaan MRT (JKKP, 2015). Kemalangan maut juga pernah berlaku di projek MRT pembinaan Stesen Kwasa Damansara, Kota Damansara pada 24 Februari 2016. Kemalangan maut tersebut terjadi semasa mangsa menaiki kren 'skylift' untuk memasang siling projek pembinaan tersebut. Kren yang dinaiki mangsa mengalami kerosakan sistem hidraulik menyebabkan 'skylift' berkenaan meluncur dan melanggar besi pada stesen MRT lalu mengakibatkan mangsa tersepit dan maut di tempat kejadian (JKKP, 2016b).

Berdasarkan kajian literatur dan kes-kes kemalangan pekerjaan di industri pembinaan rel yang telah dibincangkan, didapati bahawa wujudnya keperluan kajian di Malaysia dalam mengkaji faktor bahan dan peralatan yang dipercayai menjadi penyumbang kepada sebahagian besar kemalangan pekerjaan di industri pembinaan rel MRT supaya usaha untuk menambahbaik prestasi KKP di industri ini dapat direalisasikan. Berdasarkan kajian literatur juga dapat dirumuskan bahawa aspek-aspek penting yang sering dikaitkan dengan kemalangan pekerjaan disebabkan oleh faktor bahan dan peralatan adalah terbahagi kepada empat iaitu kesesuaian bahan/peralatan; keadaan bahan/peralatan; rekabentuk perlindungan

keselamatan; dan pengetahuan mengenai bahan/peralatan yang digunakan. Kajian-kajian terdahulu mengenai aspek-aspek kemalangan pekerjaan disebabkan faktor bahan dan peralatan dibincangkan oleh pengkaji seperti Hale et al. (2012), Li dan Guldenmund (2018), Reese \& Edison, (2006), dan Stępień (2014).

\section{a. Aspek kesesuaian bahan/peralatan}

Bagi aspek kesesuaian bahan/peralatan, Haslam et al. (2005) menyatakan bahawa kesesuaian bahan dan peralatan telah menyumbang kepada lebih daripada suku (27\%) kes kemalangan di tapak pembinaan. Haupt (2001) pula menyatakan bahawa ketersediaan bahan dan peralatan di sesuatu tapak pembinaan mungkin berbeza-beza dan memerlukan penggantian dengan bahan dan peralatan yang lain di mana pekerja mungkin tidak biasa. Aspek kesesuaian bahan dan peralatan yang boleh dikaitkan dengan kemalangan pekerjaan di industri pembinaan adalah seperti kekurangan peralatan, mesin ataupun perkakas; kebolehgunaan bahan pembinaan; kesesuaian fizikal bahan pembinaan seperti saiz yang besar dan terlalu berat; rekabentuk dan pemasangan peralatan yang tidak betul seperti perancah (Fung et al., 2012; Haslam et al., 2005; Ismail et al., 2012).

\section{b. Aspek keadaan bahan/peralatan}

Sama seperti aspek kesesuaian bahan dan peralatan, Haslam et al. (2005) mengenalpasti bahawa aspek keadaan bahan dan peralatan juga merupakan salah satu penyumbang yang 
penting kepada lebih daripada suku kes kemalangan di industri pembinaan. Antara aspek keadaan bahan dan peralatan yang sering diberi perhatian oleh penyelidik terdahulu adalah seperti peralatan dan mesin di dalam keadaan yang tidak boleh digunakan; kekurangan baikpulih peralatan, mesin dan kelengkapan; kekurangan penyelenggaraan peralatan, mesin dan kelengkapan; dan keadaan bahan binaan kurang baik (Fung et al., 2012; Hale et al., 2012; Haslam et al., 2005).

\section{c. Aspek rekabentuk perlindungan keselamatan}

Antara perkara penting yang dikaitkan dengan penyumbang kepada kemalangan di industri pembinaan bagi aspek rekabentuk perlindungan keselamatan pula adalah peralatan tanpa peranti keselamatan; peranti keselamatan yang tidak/kurang sesuai dengan tugas; peranti keselamatan tidak berfungsi; rekabentuk peralatan perlindungan peribadi yang salah/tidak sesuai; fasiliti dan langkah-langkah perlindungan keselamatan tidak/kurang sesuai bagi tindak balas kecemasan. (Fung et al., 2012; Haslam et al., 2005; Pinto et al., 2011; Ismail et al., 2012).

\section{d. Aspek pengetahuan mengenai bahan/peralatan yang digunakan}

Aspek keempat dalam faktor bahan dan peralatan adalah pengetahuan mengenai bahan dan peralatan yang digunakan oleh pekerja di tapak pembinaan. Contohnya adalah seperti penggunaan bahan dan peralatan yang tidak betul; kekurangan arahan dan penstoran bahan dan peralatan yang tidak betul; pelaksanaan dan penyelenggaraan bahan yang tidak betul; kekurangan dan melaksanakan penilaian risiko yang tidak betul terhadap penggunaan bahan dan peralatan; dan ketiadaan manual rujukan mengenai cara penggunaan peralatan dengan betul (Cheng et al., 2010; Fung et al., 2012; Haslam et al., 2005; Obolewicz, 2011; Ismail et al., 2012).

\section{Model faktor bahan dan peralatan}

Berdasarkan rujukan literatur yang dibuat, satu model pengukuran telah dibangunkan bagi mengesahkan perhubungan di antara pemboleh ubah pendam dengan pemboleh ubah yang diperhatikan melalui Rajah 1. Model pengukuran atau juga dikenali sebagai model hipotesis dibentuk oleh perhubungan antara pemboleh ubah pendam, pemboleh ubah indikator dan ralat varians (Chua, 2009; Schreiber et al., 2006). Merujuk kepada Rajah 1, pemboleh ubah pendam adalah faktor bahan dan peralatan; aspek kesesuaian bahan dan peralatan; keadaan bahan dan peralatan; rekabentuk perlindungan keselamatan; dan pengetahuan mengenai bahan dan peralatan yang digunakan. Manakala pemboleh ubah yang diperhatikan pula merupakan 19 item bagi keempat-empat aspek di bawah faktor bahan dan peralatan. Kesemua pemboleh ubah yang diperhatikan tersebut boleh diperolehi melalui pengumpulan data terhadap syarikat industri yang disasarkan. Manakala pemboleh ubah pendam ialah faktor bahan dan peralatan. 


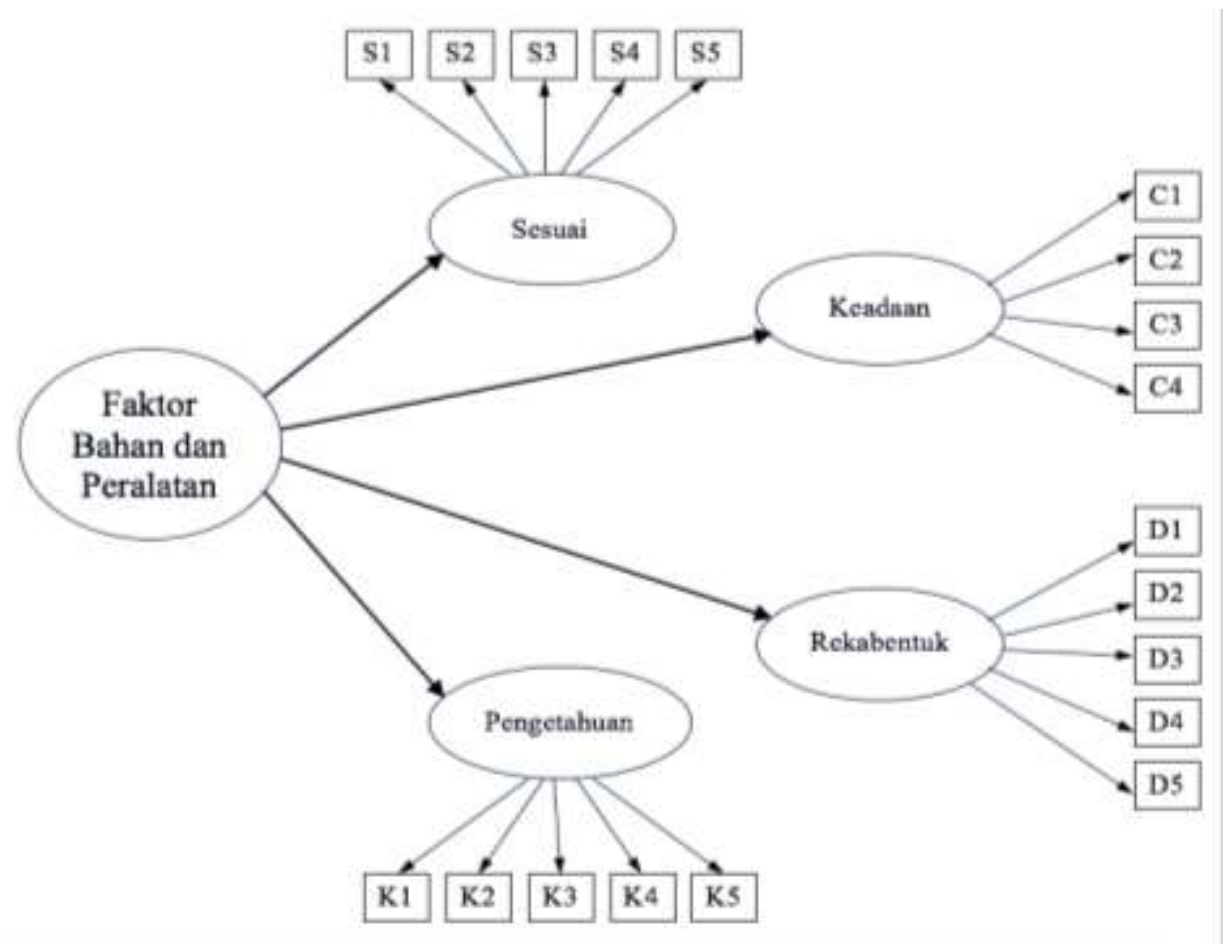

Rajah 1. Model pengukuran faktor bahan dan peralatan

\section{Metodologi kajian}

\section{Reka bentuk soal selidik}

Kajian kuantitatif ini dijalankan di mana borang soal selidik merupakan kaedah utama bagi mendapatkan data. Satu set soal kaji selidik telah disediakan merangkumi 19 soalan berkaitan empat aspek di bawah faktor bahan dan peralatan dalam menyumbang kepada kemalangan pekerjaan dalam industri pembinaan MRT dan telah dibangunkan berdasarkan kajian literatur (Jadual 1). Keempat-empat aspek tersebut merangkumi aspek kesesuaian bahan/peralatan (5 soalan); keadaan bahan/peralatan (4 soalan); rekabentuk perlindungan keselamatan (5 soalan); dan pengetahuan mengenai bahan/peralatan yang digunakan (5 soalan). Soalan di Bahagian B adalah disampaikan berdasarkan 5 titik skala Likert (1= Sangat tidak setuju, $5=$ Sangat setuju). Seramai tiga orang pensyarah kanan universiti tempatan yang mempunyai latar belakang keselamatan dan kesihatan pekerjaan telah dirujuk untuk mendapatkan pengesahan tentang kesahan muka dan kesahan kandungan bagi soal selidik yang dibangunkan.

Sebelum kajian sebenar dijalankan, kajian rintis telah dijalankan untuk memastikan kebolehpercayaan dan kesignifikanan bagi kesemua item di dalam borang soal selidik dengan menggunakan prosedur alfa Cronbach yang diasaskan kepada model konsistensi dalaman. Nilai pekali alfa Cronbach bagi borang soal selidik yang merangkumi kesemua aspek yang dikaji ialah di antara 0.871 hingga 0.913 di mana ia dianggap mempunyai kebolehpercayaan yang tinggi dan mempunyai konsistensi responden yang bagus (George \& Mallery, 1995; Pallant, 2010). 
Jadual 1. Senarai faktor bahan dan peralatan mengikut aspek

\begin{tabular}{|c|c|c|}
\hline Aspek & Label & Kandungan \\
\hline \multirow{5}{*}{$\begin{array}{c}\text { Kesesuaian } \\
\text { bahan/ } \\
\text { peralatan }\end{array}$} & S1 & $\begin{array}{l}\text { Kekurangan peralatan, mesin ataupun perkakas yang bersesuaian untuk } \\
\text { pemeriksaan keselamatan. }\end{array}$ \\
\hline & $\mathrm{S} 2$ & Kebolehgunaan bahan pembinaan yang tidak/ kurang sesuai dengan tugas. \\
\hline & $\mathrm{S} 3$ & $\begin{array}{l}\text { Fizikal bahan pembinaan tidak/ kurang sesuai seperti saiz yang besar dan terlalu } \\
\text { berat. }\end{array}$ \\
\hline & $\mathrm{S} 4$ & Bahan dan peralatan yang digunakan tidak bersesuaian dengan tugas. \\
\hline & S5 & Rekabentuk dan pemasangan peralatan yang tidak betul. \\
\hline \multirow{4}{*}{$\begin{array}{l}\text { Keadaan } \\
\text { bahan/ } \\
\text { peralatan }\end{array}$} & $\mathrm{C} 1$ & $\begin{array}{l}\text { Peralatan dan mesin yang disediakan dalam keadaan yang tidak boleh digunakan/ } \\
\text { tidak elok. }\end{array}$ \\
\hline & $\mathrm{C} 2$ & Peralatan, mesin dan kelengkapan yang digunakan tidak dibaikpulih dengan betul. \\
\hline & $\mathrm{C} 3$ & Peralatan, mesin dan kelengkapan yang digunakan tidak diselenggara dengan betul. \\
\hline & $\mathrm{C} 4$ & Keadaan bahan binaan yang digunakan adalah kurang baik. \\
\hline \multirow{5}{*}{$\begin{array}{l}\text { Rekabentuk } \\
\text { perlindungan } \\
\text { keselamatan }\end{array}$} & D1 & Peralatan dan mesin yang digunakan tidak mempuyai peranti keselamatan. \\
\hline & D2 & $\begin{array}{l}\text { Peralatan dan mesin yang digunakan mempuyai peranti keselamatan yang tidak/ } \\
\text { kurang sesuai dengan tugas. }\end{array}$ \\
\hline & D3 & Peranti keselamatan pada peralatan dan mesin tidak berfungsi dengan betul. \\
\hline & D4 & $\begin{array}{l}\text { Peralatan perlindungan peribadi (PPE) yang digunakan mempunyai rekabentuk } \\
\text { keselamatan yang salah/ tidak sesuai dengan tugas. }\end{array}$ \\
\hline & D5 & $\begin{array}{l}\text { Fasiliti dan langkah-langkah perlindungan keselamatan tidak/ kurang sesuai bagi } \\
\text { tindak balas kecemasan. }\end{array}$ \\
\hline \multirow{5}{*}{$\begin{array}{l}\text { Pengetahuan } \\
\text { mengenai } \\
\text { bahan/ } \\
\text { peralatan yang } \\
\text { digunakan }\end{array}$} & K1 & Penggunaan bahan dan peralatan yang tidak betul oleh pekerja. \\
\hline & $\mathrm{K} 2$ & Kekurangan arahan dan penstoran bahan dan peralatan yang tidak betul. \\
\hline & $\mathrm{K} 3$ & Pelaksanaan dan penyelenggaraan bahan yang tidak betul. \\
\hline & K4 & $\begin{array}{l}\text { Kekurangan dan melaksanakan penilaian risiko yang tidak betul terhadap } \\
\text { penggunaan bahan dan peralatan. }\end{array}$ \\
\hline & K5 & Tiada manual rujukan mengenai cara penggunaan peralatan dengan betul. \\
\hline
\end{tabular}

\section{Populasi dan sampel kajian}

Populasi dan sampel kajian ini tertumpu kepada lokasi kajian iaitu projek pembinaan MRT jajaran Sungai Buloh-Serdang-Putrajaya (SBSP) sepanjang 52.2 kilometer yang dijangka siap sepenuhnya pada tahun 2022 (MRT Corp. 2017). Populasi dan sampel kajian adalah melibatkan semua pekerja tempatan di projek pembinaan MRT jajaran SBSP yang terdiri daripada dua kumpuan iaitu, (1) kumpulan pengurusan/profesional yang mempengaruhi proses merancang, melaksana dan memantau pengurusan KKP di tapak pembinaan, (2) kumpulan pekerja pembinaan iaitu pekerja yang bekerja secara langsung di tapak pembinaan. Dua kumpulan responden ini dipilih kerana ia mampu mewakili keseluruhan populasi kajian dan seterusnya dapatan kajian iaitu model yang dibangunkan dapat digeneralisasikan kepada seluruh populasi industri pembinaan rel MRT (Chua, 2009).

Penetapan saiz sampel adalah berasaskan kepada pendapat penyelidik Iacobucci (2010) dan Kline (1996). Menurut Iacobucci (2010), saiz sampel sebanyak 150 responden adalah memadai untuk analisis CFA. Kline (1996) pula berpendapat bahawa saiz sampel di bawah 100 responden adalah tidak sesuai untuk analisis CFA. Oleh itu, jumlah keseluruhan sampel yang ditetapkan adalah 180 orang merangkumi 79 orang dari kumpulan pengurusan/profesional, dan 101 orang dari kumpulan pekerja pembinaan.

\section{Kaedah pengumpulan dan analisis data}

Sampel kajian dipilih secara rawak daripada populasinya di mana setiap kontraktor projek pembinaan MRT terlibat dengan kaji selidik ini dengan bantuan bahagian keselamatan dan 
kesihatan syarikat masing-masing. Responden diberikan beberapa arahan semasa menjawab kaji selidik seperti: (1) penglibatan mereka secara sukarela dan mereka boleh menarik diri dari kajian pada bila-bila masa, (2) semua soal selidik perlu dijawab sendiri oleh responden, dan (3) perbincangan dengan rakan mengenai soal selidik adalah tidak dibenarkan. Antara kriteria pemilihan responden adalah seperti: (1) pekerja tempatan, (2) mempunyai pengetahuan asas berkaitan KKP, dan (3) terlibat dengan kerja-kerja projek pembinaan MRT jajaran SBSP. Borang soal selidik diedarkan kepada responden melalui dua cara iaitu, (1) edaran terus kepada responden melalui pertemuan di tapak pembinaan dan lain-lain tempat, (2) edaran elektronik (Google Forms) seperti email dan pesanan ringkas dan responden diingatkan melalui panggilan telefon. Sebanyak 95 maklumbalas diperolehi melalui edaran terus, manakala 85 maklumbalas selebihnya diperolehi melalui edaran elektronik. Keseluruhan maklumbalas responden yang diperolehi ialah sebanyak 180.

Data-data yang diperoleh daripada responden dianalisis menerusi kaedah CFA dengan menggunakan perisian IBM SPSS-AMOS Version 23. Sebelum CFA dilakukan, analisis Exploratory Factor Analysis (EFA) perlu dijalankan ke atas data kajian yang diperolehi daripada responden. EFA telah dijalankan dengan menggunakan perisian IBM SPSS Statistics Version 23. Kemudian, analisis CFA dijalankan ke atas data kajian iaitu pemboleh ubah yang diperhatikan untuk menguji dan mengesahkan hubungan struktur faktor set pemboleh ubah yang diukur berdasarkan nilai kesepadanan model (model fit) (Hoyle, 2012; SchermellehEngel et al., 2003).

\section{Keputusan kajian dan perbincangan}

\section{EFA (Analisis awal)}

Aplikasi utama bagi menjalankan analisis EFA adalah untuk mengesan struktur-struktur di dalam hubungan antara pemboleh ubah untuk dikategorikan mengikut susunan konstrukkonstruk tertentu dan mengurangkan pemboleh ubah yang saling berkaitan (bertindih) untuk menjadi jumlah yang lebih kecil (Chua, 2009; Hoyle, 2012; Thompson, 2004).

Di dalam kajian ini, EFA dijalankan dengan menggunakan analisis komponen principal dengan pemutaran Varimax ke atas 19 item bagi mengukur faktor bahan dan peralatan dalam menyumbang kepada kemalangan pekerja di sektor pembinaan MRT. Jadual 2 menunjukkan keputusan prosedur pemutaran Varimax iaitu Komponen Matrik Berputar (Rotated Component Matrix). Merujuk kepada Jadual 2, didapati keseluruhan 19 item yang dikaji telah dikurangkan kepada 16 item setelah 3 item (S5, K1, K2) disingkirkan kerana mempunyai nilai pemberat faktor (factor loading) kurang daripada had minimum 0.6. Ini adalah kerana hanya nilai pemberat faktor yang melebihi had 0.6 merupakan kriteria bagi pengukuran pemboleh ubah yang boleh diterima (Zainudin, 2012).

Kekuatan pengukuran model melalui EFA ditentukan oleh ujian kebolehpercayaan alfa Crobach. Nilai kebolehpercayaan item yang telah dibina bagi mewakili sesuatu faktor boleh diterima jika nilai pekali alfa Cronbach $>0.7$ untuk diterima pakai dalam ujian CFA seterusnya (Pallant, 2010). Keputusan menunjukkan nilai alfa Cronbach untuk setiap konstruk adalah 0.932, 0.907, 0.877 dan 0.853 (lihat Jadual 2) dan ini bermakna semua instrumen tersebut boleh diterima pakai dalam analisis CFA kerana mempunyai kebolehpercayaan yang tinggi. 
Jadual 2. Keputusan EFA bagi faktor bahan dan peralatan

\begin{tabular}{|c|c|c|c|c|c|}
\hline \multirow{2}{*}{ Item } & \multicolumn{4}{|c|}{ Nilai Pemberat Faktor } & \multirow{2}{*}{$\begin{array}{l}\text { Nilai pekali alfa } \\
\text { Cronbach }\end{array}$} \\
\hline & Sesuai & Keadaan & Rekabentuk & Pengetahuan & \\
\hline S1 & 0.862 & & & & \multirow{4}{*}{0.932} \\
\hline S2 & 0.757 & & & & \\
\hline S3 & 0.718 & & & & \\
\hline S4 & 0.639 & & & & \\
\hline $\mathrm{C} 2$ & & 0.839 & & & \multirow{4}{*}{0.907} \\
\hline $\mathrm{C} 1$ & & 0.793 & & & \\
\hline $\mathrm{C} 3$ & & 0.736 & & & \\
\hline $\mathrm{C} 4$ & & 0.631 & & & \\
\hline D2 & & & 0.807 & & \multirow{5}{*}{0.877} \\
\hline D1 & & & 0.798 & & \\
\hline D4 & & & 0.731 & & \\
\hline D5 & & & 0.698 & & \\
\hline D3 & & & 0.633 & & \\
\hline K5 & & & & 0.748 & \multirow{3}{*}{0.853} \\
\hline K3 & & & & 0.671 & \\
\hline K4 & & & & 0.632 & \\
\hline
\end{tabular}

\section{CFA (model pengukuran)}

Bagi menentukan kesepadanan model pengukuran, terdapat empat kriteria ujian indeks kesepadanan yang telah digunakan di dalam kajian iaitu, Ujian Khi Kuasa Dua $x^{2} / d f$; Absolute Fit Root Mean Square Error Approximation (RMSEA); Incremental Fit Comparative Fit Index (CFI); dan Parsimonious Fit PNFI seperti di Jadual 3 (Arbuckle, 2011; Byrne, 2009; Hair et al., 2014; Chen \& Fong, 2012). Keputusan analisis CFA adalah seperti ditunjukkan di Jadual 3. Analisis CFA yang pertama menunjukkan keputusan tidak memenuhi tiga kriteria ujian indeks kesepadanan yang ditetapkan iaitu $x^{2} / d f$, RMSEA dan CFI. Oleh itu, model pengukuran perlu diubah suai (modifikasi) sehingga memenuhi keempat-empat kriteria ujian indeks kesepadanan. Menurut Arbuckle (2011), terdapat tiga cara untuk mengubah suai model sehingga mencapai kesepadanan iaitu dengan menghapuskan item yang mempunyai nilai pemberat faktor yang minimum; menggabungkan dua item kepada satu; dan menambah hubungan kovarians. Dalam kajian ini, satu item yang mempunyai nilai pemberat faktor yang minimum (S1) telah dihapuskan dan tiga hubungan kovarians telah ditambah bagi mencapai kesepadanan model pengukuran. Model CFA selepas proses modifikasi telah memenuhi keempat-empat kriteria ujian indeks kesepadanan dan ia bererti bahawa model tersebut secara signifikan sepadan dengan data kajian.

Jadual 3. Kesepadanan model analisis CFA

\begin{tabular}{cccc}
\hline \multirow{2}{*}{ Indeks Kesepadanan } & Kriteria & \multicolumn{2}{c}{ Model CFA } \\
\cline { 3 - 4 } & Penilaian & Sebelum kesepadanan & Selepas kesepadanan \\
\hline Khi Kuasa Dua $\chi^{2} / d f$ & $<3.00$ & 4.432 & 2.537 \\
Absolute Fit RMSEA & $<0.10$ & 0.139 & 0.093 \\
Incremental Fit CFI & $>0.90$ & 0.724 & 0.912 \\
Parsimonious Fit PNFI & $>0.50$ & 0.583 & 0.684 \\
\hline
\end{tabular}

kemalangan pekerjaan di industri pembinaan MRT yang telah disahkan melalui analisis CFA yang melalui proses modifikasi. Keputusan CFA modifikasi bagi model pengukuran menunjukkan bahawa nilai critical ratio bagi regresi antara semua pemboleh ubah pendam dengan pemboleh ubah yang diperhatikan adalah di luar lingkungan $\pm 1.96(\mathrm{p}<.05)$. Ini bermakna bahawa semua pemboleh ubah yang diperhatikan merupakan pemboleh ubah 
peramal yang signifikan bagi pemboleh ubah pendam di dalam model pengukuran (Chua, 2009). Di samping itu, dengan merujuk pada rajah 2, didapati bahawa nilai pekali regresi piawai adalah tinggi iaitu di antara 0.58 hingga 0.98 dan ia menunjukkan bahawa semua pemboleh ubah yang diperhatikan mewakili pemboleh ubah pendam mereka secara signifikan.

\section{Dapatan kajian}

Hasil kajian menunjukkan bahawa empat aspek bagi faktor bahan dan peralatan dapat ditentukan melalui prosedur EFA; manakala CFA pula mengesahkan kesahihan konstruknya. Rajah 2 menunjukkan bahawa keempat-empat aspek iaitu "sesuai" ( $\beta=0.61)$, "keadaan" $(\beta=$ 0.82), "rekabentuk" $(\beta=0.86)$, dan "pengetahuan" $(\beta=0.98)$ mempunyai pengaruh positif yang signifikan terhadap faktor bahan dan peralatan. Dapatan ini menunjukkan bahawa faktor bahan dan peralatan yang menyumbang kepada kemalangan pekerjaan alam industri pembinaan MRT adalah terdiri daripada keempat aspek tersebut.

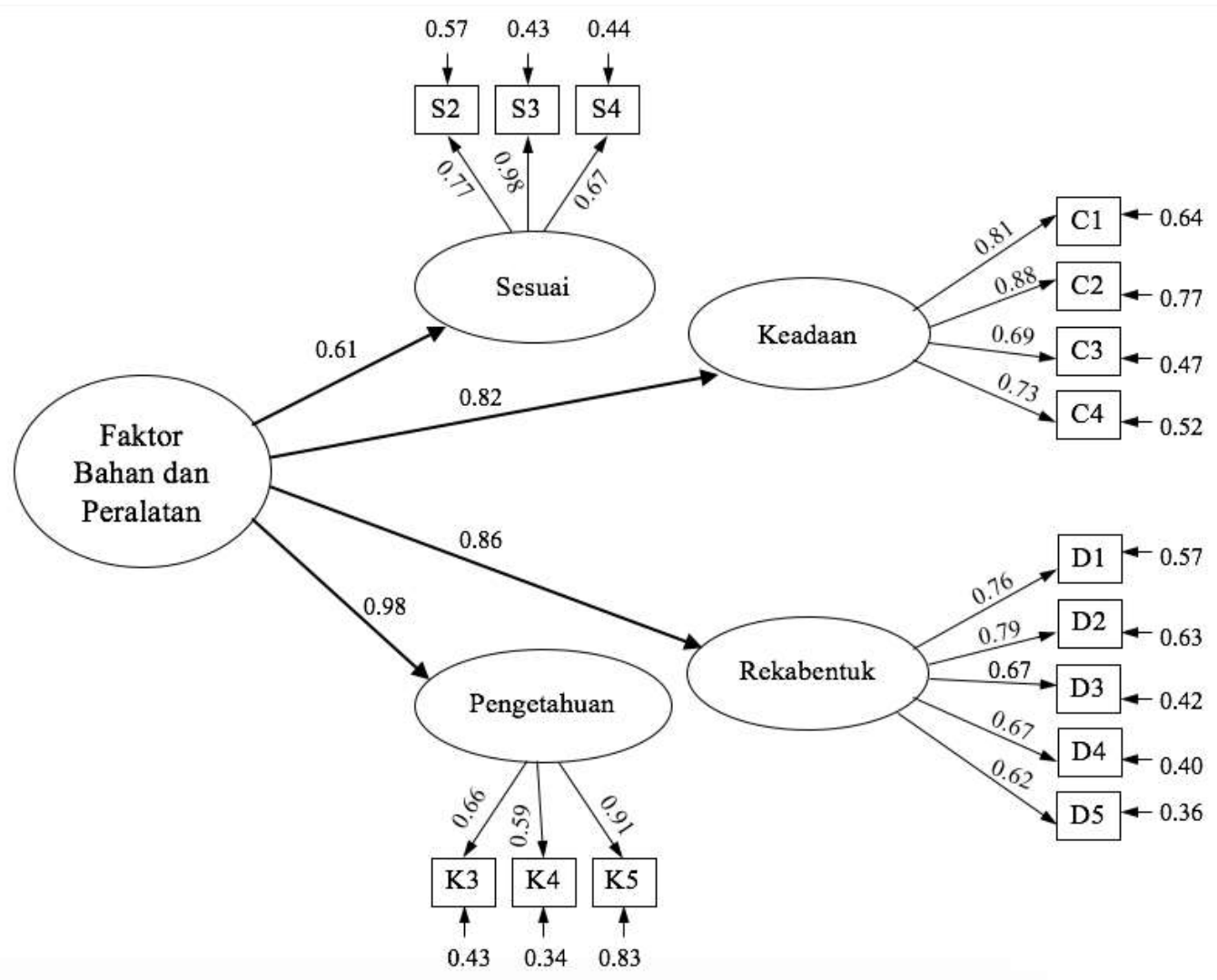

Rajah 2. Model akhir faktor bahan dan peralatan

Aspek "pengetahuan" perlu diberi perhatian dalam menangani isu berkaitan dengan faktor bahan dan peralatan di industri pembinaan MRT kerana mencatatkan pekali regresi piawai yang tertinggi $(\beta=0.98)$. Tidak dapat dinafikan bahawa pengetahuan pekerja mahupun penyelia di tapak pembinaan berkaitan penggunaan, penstoran, penyelenggaraan dan penaksiran risiko berkaitan bahan dan peralatan adalah sangat penting untuk mengurangkan risiko berlakunya kemalangan pekerjaan (Endroyo et al., 2015). Salah satu cara untuk meningkatkan tahap pengetahuan pekerja tapak pembinaan adalah melalui latihan (Raheem \& Issa 2016). Lai et al. (2011) melalui kajiannya mendapati bahawa latihan keselamatan adalah kaedah paling efektif bagi mengurangkan hazad kerana ia dapat 
membantu untuk meningkatkan pengetahuan, kemahiran dan kebolehan pekerja pembinaan untuk mengenalpasti hazad berkaitan dengan bahan dan peralatan yang digunakan. Aspek "pengetahuan" yang paling penting untuk peningkatan keselamatan di industri pembinaan MRT adalah menyediakan manual lengkap mengenai cara menggunakan peralatan dan mesin dengan betul; pelaksanaan dan penyelenggaraan bahan dan peralatan pembinaan yang baik; dan melaksanakan penilaian risiko yang betul mengenai bahan dan peralatan. Sementara itu, tindakan yang bertanggungjawab oleh pihak pengurusan adalah diperlukan untuk pelaksanaan intervensi ini di tapak pembinaan.

Aspek "rekabentuk" ( $\beta=0.86)$ dan "keadaan" ( $\beta=0.82)$ juga perlu dititikberatkan kerana mencatatkan pekali regresi piawai yang tinggi. Kedua-dua aspek ini memainkan peranan yang penting bagi keselamatan pekerja di tapak pembinaan. Haslam et al. (2005) menyatakan bahawa aspek rekabentuk bahan dan peralatan yang digunakan di tapak pembinaan adalah perlu diberi perhatian kerana ia terbukti telah menyumbang kepada kes-kes kemalangan. Wong et al. (2020), dalam kajiannya mendapati rekabentuk PPE adalah salah satu faktor yang penting bagi kebolehgunaannya di kalangan pekerja pembinaan bagi mengurangkan risiko kecederaan jika berlakunya kemalangan. Dapatan kajian menunjukkan bahawa, aspek "rekabentuk" yang perlu diberi fokus adalah menyediakan peranti keselamatan bagi peralatan dan mesin yang bersesuaian dengan tugasan; rekabentuk PPE yang sesuai; dan fasiliti dan langkah perlindungan keselamatan yang sesuai bagi tindak balas kecemasan. Keadaan bahan dan peralatan yang digunakan di industri pembinaan juga telah menyumbang kepada banyak kes kemalangan dan wajar diberi penekanan dari segi keselamatan penggunaannya (Fung et al. 2012; Hale et al. 2012). Oleh itu, dapatan kajian ini menunjukkan bahawa intervensi keselamatan yang perlu dilaksanakan berkaitan dengan aspek "keadaan" adalah dengan memastikan kebolehgunaan semua peralatan dan mesin; rutin baikpulih dan senggaraan; dan keadaan peralatan, mesin dan kelengkapan yang baik digunakan di tapak pembinaan.

\section{Kesimpulan}

Di Malaysia, kadar kemalangan pekerjaan dan kemalangan maut di industri pembinaan umumnya dan industri pembinaan rel MRT khususnya adalah sangat tinggi. Pelbagai faktor dikaitkan kepada penyumbang kepada kemalangan pekerjaan seperti manusia (pekerja); tempat kerja; bahan dan peralatan; pengurusan; dan pengaruh persekitaran. Terdapat banyak usaha yang dilakukan oleh pelbagai pihak bagi menambahbaik prestasi KKP di dalam industri ini. Kajian ini memberi penekanan kepada faktor bahan dan peralatan dalam menyumbang kepada kemalangan pekerjaan dalam industri pembinaan rel MRT di Malaysia melalui pendekatan analisis kuantitatif. Keputusan CFA menunjukkan bahawa model faktor bahan dan peralatan mempunyai indeks kesesuaian yang boleh diterima (goodness of fit) di mana ia terdiri daripada empat aspek iaitu kesesuaian bahan dan peralatan; keadaan bahan dan peralatan; rekabentuk perlindungan keselamatan; dan pengetahuan mengenai bahan dan peralatan yang digunakan. Hasil dapatan kajian ini iaitu model yang dibangunkan boleh dijadikan rujukan kepada semua pemegang taruh di dalam industri pembinaan rel MRT seperti pemaju, perekabentuk, penguatkuasa, pusat latihan keselamatan pekerjaan dan lainlain dengan memberi penekanan terhadap aspek- aspek-aspek yang bersesuaian di bawah faktor bahan dan peralatan bagi mencegah kemalangan pekerjaan daripada berlaku di masa akan datang. 


\section{Penghargaan}

Penulis ingin merakamkan setinggi-tinggi penghargaan dan terima kasih kepada Program Pengurusan Persekitaran, FSKK, Universiti Kebangsaan Malaysia; pihak MRT Corp. Sdn. Bhd.; dan Jabatan Keselamatan dan Kesihatan Pekerjaan Malaysia di atas kerjasama dan bantuan dalam menjalankan penyelidikan ini.

\section{Rujukan}

Arbuckle, J.L., (2011). Amos (20.0). Crawfordville, FL: Amos Development Corporation

Arifin, K., Aiyub, K., Razman, M.R., Jahi, J.M., Awang, A., \& Hussain, S.S.H. (2013). Occupational safety management in Malaysia. Journal of Food, Agriculture and Environment, 11(2), 995-998.

Arifin, K., Abudin, R., Razman, M.R., Ismail, Z.S. \& Ahmad, M., (2016). Safety climate assessment on priority, commitment and the efficiency of safety management. Journal of Food, Agriculture and Environment. 14(2): 142-146.

Byrne, B. (2009). Structural Equation Modeling with AMOS - Basic concepts, applications, and programming.

Cao, J. H. (2013). The Research of RAMS management in China's high-speed railway construction project. Engineering Management, 559-571. doi:10.1007/978-3-64238433-2_61

Chen, L., \& Fong, P.S.W. (2012). Revealing performance heterogeneity through knowledge management maturity evaluation: a capability-based approach. Expert Syst. Appl. 39(18), 13523-13539.

Cheng, C.W., Leu, S.S., Lin, C.C. \& Fan, C. (2010). Characteristic analysis of occupational accidents at small construction enterprises. Safety Science, 48, 698-707.

Choe, S., Leite, F. (2020). Transforming inherent safety risk in the construction industry: A safety risk generation and control model. Safety Science, 124, 225-238.

Chua, Y.P. (2009). Statistik penyelidikan lanjutan. Kuala Lumpur: McGraw-Hill (Malaysia) Sdn. Bhd.

Dzuhailmi, D., Silva, J.L.D., Abdullah, H., Ismail, I.A., \& Ahmad, N. (2015). Youth confidence in the quality of public transport services: The case of Greater KL , Geografia-Malaysian Journal of Society and Space, 9(9), 12-22.

Endroyo, B., Yuwono, B.E., Mardapi, D. \& Soenarto. (2015). Model of learning/training of occupational safety and health $(\mathrm{OSH})$ based on industry in the construction industry. Procedia Engineering, 125, 83-88.

Fass, S., Yousef, R., Liginlal, D. \& Vyas, P. (2017). Understanding causes of fall and struckby incidents: What differentiates construction safety in the Arabian Gulf region? Applied Ergonomics, 58, 515-526.

Filho, A.P.G., Mateus, C.C.S., Oliveira, D.S.V, Andrade, E.G. \& Muniz, M.P. (2002). The Impacts of human factors in fatal workplace accidents. International Conference on Industrial Engineering and Operations Management (ICIEOM), 1-8.

Fung, I.W.H., Lo, T.Y., Tung, K.C.F. (2012). Towards a better reliability of risk assessment: Development of a qualitative \& quantitative risk evaluation model (Q2REM) for different trades of construction works in Hong Kong. Accident Analysis and Prevention, 48, 167-184.

Gürcanli, G.E. \& Müngen, U. (2013). Analysis of construction accidents in Turkey and responsible parties. Industrial health, 51(6), 581-95. doi:10.2486/indhealth.2012-0139

George D, Mallery P. (1995). SPSS/PC+ Step by step. California: Wadsworth Publishing Company. 
Hair, J.F., Black, W.C., Babin, B.J. \& Anderson, R.E. (2014). Multivariate data analysis. Edisi ke-7. Upper Saddle River, NJ: Prentice Hall.

Hale, A. Walker, D., Walters, N. \& Bolt, H. (2012). Developing the understanding of underlying causes of construction fatal accidents. Safety Science, 50(10), 2020-2027.

Haslam, R.A., Hide, S.A., Gibb, A.G.F., Gyi, D.E., Pavitt, T., Atkinson, S. \& Duff, A.R. (2005). Contributing factors in construction accidents. Applied ergonomics, 36(4), 40115.

Haupt, T. (2001). The performance approach to construction worker safety and health (December), 372. Retrieved from http://purl.fcla.edu/fcla/etd/ufe0000322

Hide, S., Atkinson, S., Haslam, R., Gibb, A., Gyi, D., Duff, R. \& Suraji, A. (2003). Causal factors in construction accidents. Health and Safety Executive HSE,.

Hoyle, R.H. (2012). Handbook of Structural Equation Modeling. New York: Guilford Publications, Inc.

Hughes, P. \& Ferrett, E. (2005). Introduction to health and safety in construction. Oxford: Elsevier Butterworth-Heinemann.

Hyoung, J.I., Young, J.K., Soo, G.K., Yong, K.K., Young, S.J., Hwa, P.L. (2009). The charatersitisc of fatal occupational injuries in Korea Construction Industry 1997-2004. Safety Science, 47(8), 1159-1162.

Iacobucci, D. (2010). Structural equations modeling: fit indices, sample size, and advanced topics. J. Consum. Psychol. 20, 90-98.

Ismail, Z., Doostdar, S. \& Harun, Z. (2012). Factors influencing the implementation of a safety management system for construction sites. Safety Science, 50(3), 418-423.

Ismail, Z.S., Arifin, K., Aiyub, K., Razman, M.R., Derahim, N. \& Abbas, N.N. (2017). Assessing of safety culture in the research university in Malaysia. Journal of Food, Agriculture and Environment. 15(2): 102-106.

Jaafar, M.H., Arifin, K., Aiyub, K., Razman, M.R. \& Ahmad, M. (2015). A review of occupational safety and health (OSH) accidents and contributing factors in construction industry. Journal of Food, Agriculture \& Environment, 13(2), 238-244.

Jaafar, M.H., Arifin, K., Aiyub, K., Razman, M.R., Ishak, M.I.S. \& Samsurijan, M.S. (2018). Occupational safety and health management in the construction industry: a review. International Journal of Occupational Safety and Ergonomics, 24(4), 493-506.

Jabatan Keselamatan dan Kesihatan Pekerjaan Malaysia. (2013). Laporan awal kemalangan maut di tapak pembinaan MRT di Subang, Putrajaya: Kementerian Sumber Manusia.

Jabatan Keselamatan dan Kesihatan Pekerjaan Malaysia. (2015). Laporan awal kemalangan maut di tapak pembinaan MRT Semantan, Putrajaya: Kementerian Sumber Manusia.

Jabatan Keselamatan dan Kesihatan Pekerjaan Malaysia. (2016a). Statistik kemalangan pembinaan MRT di Malaysia. Putrajaya: Kementerian Sumber Manusia.

Jabatan Keselamatan dan Kesihatan Pekerjaan Malaysia. (2016b). Laporan awal kemalangan maut di tapak pembinaan MRT Stesen Kwasa Damansara, Kota Damansara. Putrajaya: Kementerian Sumber Manusia.

Jabatan Keselamatan dan Kesihatan Pekerjaan Malaysia. (2019). Statistik data ringkas JKKP. Putrajaya: Kementerian Sumber Manusia.

Jabbari, M. \& Ghorbani, R. 2016. Developing techniques for cause-responsibility analysis of occupational accidents. Accident Analysis and Prevention, 96, 101-107.

Jamilah, M. (2005). Urban transport and growth management strategies: A tale of two Southeast Asian cities at the dawn of the new millennium. Geografia-Malaysian Journal of Society and Space 1(1), 11-22.

Kang, K., Ryu, H. (2019). Predicting types of occupational accidents at construction sites in Korea using random forest model. Safety Science, 120, 321-335.

Khanzode, V.V., Maiti, J. \& Ray, P.K. (2012). Occupational injury and accident research: A 
comprehensive review. Safety Science, 50(5), 1355-1367.

Khosravi, Y., Asilian-Mahabadi, H., Hajizadeh, E., Hassanzadeh-Rangi, N., Bastani, H., \& Behzadan, A.H. (2014). Factors influencing unsafe behaviors and accidents on construction sites: A review. International Journal of Occupational Safety and Ergonomics, 20(1), 111-125.

Kline P. (1996). An easy guide to factor analysis. Great Britain: Routledge.

Lai, D.N.C., Liu, M., \& Ling, F.Y.Y. (2011). A comparative study on adopting human resource practices for safety management on construction projects in the United States and Singapore, International Journal of Project Management, 29, 1018-1032.

Lee, Y.C., Shariatfar, M., Rashidi, A., Lee, H.W. (2020). Evidence-driven sound detection for prenotification and identification of construction safety hazards and accidents. Automation in Construction, 113, 152-165.

Li, Y. \& Guldenmund, F.W. (2018). Safety management systems: A broad overview of the literature, Safety Science, 103, 94-123.

Misiurek, K. \& Misiurek, B. (2017). Methodology of improving occupational safety in the construction industry on the basis of the TWI program. Safety Science, 92, 225-231. doi:10.1016/j.ssci.2016.10.017

MRT Corp. (2017). MRT Sungai Buloh-Serdang-Putrajaya (SBSP) Line, Mass Rapid Transit Corporation Sdn. Bhd.

Obolewicz, J. (2011). Assessment of safety and health protection in construction companies, Faculty of Civil and Environmental Engineering, Białystok Politechnic.

Pallant, J. (2010). SPSS survival manual: A step by step guide to data analysis using SPSS. Edisi ke-4. Maidenhead, England: McGraw-Hill International.

Pinto, A., Nunes, I.L., \& Ribeiro, R.A. (2011). Occupational risk assessment in construction industry - Overview and reflection. Safety Science, 49, 616-624.

Qing, L., Rengkui, L., Jun, Z., \& Quanxin, S. (2014). Quality risk management model for railway construction projects. Procedia Engineering, 84, 195-203.

Raheem, A.A., \& Issa, R.R.A. (2016). Safety implementation framework for Pakistani construction industry. Safety Science, 82, 301-314.

Reese, C.D., \& Edison, J.V. (2006). Handbook of OSHA construction safety and health. CRC Press: Boca Raton.

Schermelleh-Engel, K., Moosbrugger, H., \& Müller, H. (2003). Evaluating the fit of structural equation models: tests of significance and descriptive goodness-of-fit measures. Meth. Psychol. Res. Online, 8(2), 23-74.

Schreiber, J.B., Nora, A., Stage, F.K., Barlow, E.A., \& King, J., (2006). Reporting structural equation modeling and confirmatory factor analysis results: a review. J. Educ. Res., 99(6), 323-338.

Stępień, T. 2014. Identification of Factors Determining Accident Rate in Construction Industry. Technical Transactions Civil Engineering, 1-B/2004, 265-281.

Thompson, B. (2004). Exploratory and confirmatory factor analysis: Understanding concepts and applications. American Psychological Association.

Wong, T.K.M., Man, S.S., \& Chan, A.H.S. (2020). Critical factors for the use or non-use of personal protective equipment amongst construction workers. Safety Science, 126, 95109.

Yoon, S.J., Lin, H.K., Chen, G., Yi, S., Choi, J., \& Rui, Z. (2013). Effect of occupational health and safety management system on work-related accident rate and differences of occupational health and safety management system awareness between managers in South Korea's construction industry. Safety and Health at Work, 4(4), 201-209.

Zainudin, A. (2012). Research Methodology and Data Analysis. Shah Alam: Penerbit Universiti Teknologi MARA Press. 